\title{
Searching for common ground, a scientific approach to subjective envi- ronmental impact assessments: an example from the Kgalagadi Trans- frontier Park
}

\section{J.G. Castley, H. Bezuidenhout and M.H. Knight}

Castley, J.G., H. Bezuidenhout and M.H. Knight. 2003. Searching for common ground, a scientific approach to subjective environmental impact assessments: an example from the Kgalagadi Transfrontier Park. Koedoe 46(1): 107-114. Pretoria. ISSN 0075-6458.

In order to break away from the frequent subjective nature of assessing potential environmental impacts and alternative scenarios when undertaking new developments a structured scientific approach was adopted in the present analysis. An assessment of the proposed upgrading of a 31-km stretch of road between Leeudril and Kij-Kij waterholes on the dry Nossob River in the Kgalagadi Transfrontier Park (KTP) was undertaken. Relocation of the existing road was proposed as an alternative to upgrading the road as the potential and future impacts on the riverbed ecosystem could be reduced. A systematic assessment of biophysical variables within the riverbed habitat was made. A multivariate clustering analysis revealed a high level of congruency with a purely subjective assessment that potentially supports an "apples and oranges" comparison of such approaches in environmental assessments. Furthermore, the present and potential environmental impacts of each of the various upgrading options were compared. Significant environmental impacts were envisaged when considering surface and ground water hydrology, flora and the sensitive nature of the landscape. Given the requirements of the park in terms of providing a tourism product the preferred action in terms of upgrading the road would require a compromise between ecological and aesthetic requirements in order to provide reasonable tourism opportunities. The scientific approach adopted in the current analysis appears to offer a more defendable result upon which management decisions can be based compared to purely subjective assessments but is not without limitations.

Key words: environmental impact assessments, Kalahari, dry riverbed, road.

J.G. Castley and M.H. Knight, Conservation Services, South African National Parks, P.O. Box 20419, Humewood, 6013 Republic of South Africa (gcastley@upe.ac.za; mknight@upe.ac.za); H. Bezuidenhout, Conservation Services, South African National Parks, P.O. Box 110040, Hadison Park, 8306 Republic of South Africa(hugob@parkssa.co.za).

\section{Introduction}

Roads affect ecosystems, biological communities and species in numerous and different ways, determined largely by their location, density, and distribution across the landscape (Hourdequin 2000). Roads generally have negative effects on the biotic integrity in both terrestrial and aquatic ecosystems, and these effects can be classified under seven categories (Trombulak \& Frissell 2000): increased mortality from road construction; increased mortality from vehicle collisions; 
modification of animal behaviour; alteration of the physical environment; alteration of the chemical environment; spread of exotic species; and increased alteration and use of the habitats by humans.

In the Kgalagadi Transfrontier Park (KTP) where most of the tourist road network is constructed in the dry riverbeds of the Nossob and Auob, the impact of the roads are likely to be limited to a number of the above categories, particularly the physical and chemical properties of the surrounding ecosystems, and to a lesser extent on the mortality of animals (although plant mortality has yet to be quantified) and the modification of animal behaviour (but again where the road is in a vicinity of breeding sites this may create a problem for breeding birds).

The precise ecological effects of roads on biota may be uncertain but the selective removal, relocation and rehabilitation of roads may provide certain ecological benefits, although mitigatory measures to address these impacts may be costly, vague and have a negative impact themselves (Trombulak \& Frissell 2000).

Roads are known to alter at least eight physical characteristics of the environment, such as: soil density, temperature, soil water content, light penetration, dust production, surface water flow, run-off pattern and sedimentation.

Dust is a major factor to consider as this can settle on plants and block photosynthesis, respiration and transpiration in addition to causing physical injuries of plants (Farmer 1993), also acting as a possible deterrent to grazing. Roads on floodplains can redirect water, sediments and nutrient dispersal between streams and wetlands and their riparian ecosystems to the detriment of water quality and ecosystem health (Trombulak \& Frissel 2000). The dry riverbed systems of the KTP may be no different to these systems.

The development of road networks within protected areas to enhance the tourism potential or act as management tools (such as firebreaks) is a generally accepted practise (Pienaar 1968). However, such projects also have dramatic impacts on biodiversity conservation (Miller et al. 1995). Fortunately, the widespread adoption of environmental impact assessments (EIAs) has allowed such developments to be assessed in terms of their possible impacts on the environment and the need to assess alternatives (DEAT 1998). However, few of the experts building or 'restoring' roads are trained to recognise and address the full spectrum of ecological issues associated with road construction (Trombulak \& Frissell 2000).

The existing $490 \mathrm{~km}$ of tourist roads on the South African side of the KTP (formerly the Kalahari Gemsbok National Park) are largely restricted to the dry Nossob and Auob riverbeds, owing to the flat consolidated surfaces, and lack of permanent water (Van Wyk \& Le Riche 1984; Mills \& Retief 1984), combined with the difficulty of constructing roads in the unconsolidated sand dunes. Furthermore, the higher nutrient status of the riverbed habitat makes it the single most important habitat in the park supporting a large proportion of the indigenous ungulate populations (Mills \& Retief 1984; Knight et al. 1987). In addition, the characteristically large trees in the riverbed provide important nesting sites for most of the large raptors species (Herholdt 1995). The riverbeds, therefore, offer the best wildlife viewing potential in the park, and with the riverine habitat comprising about $4 \%$ of the $36000 \mathrm{~km}^{2}$ large KTP, it is undesirable that a relatively large proportion of it is taken up by road surface.

Along the entire length of the Auob River and the Nossob River north of Melkvlei waterhole the road has been largely moved out of the riverbed onto the calcrete footslope. However, along the $45 \mathrm{~km}$ section along the Nossob River between Twee Rivieren and Melkvlei, the road has remained in the riverbed owing to high dunes on the western bank and calcrete cliffs on the Botswanan eastern bank. This particular section, and the focus of the study, remains a management problem as the pre- 
sent ungravelled road has been lowered below the riverbed surface through continual maintenance grading. This has made it particularly prone to flooding, making it inaccessible to tourist traffic for extended periods during the summer months.

In the case of the Twee Rivieren to Melkvlei road, a number of options exist with regards to altering the road configuration within the riverbed, such as: 1) upgrading the present road within the riverbed, 2) moving the road onto the western or eastern river margins, 3 ) moving the road onto the eastern calcrete terrace, 4) or a combination of the above alternatives. The option of re-routing the road onto the western bank was disregarded at the outset as this particular section of road is characterised by high sand dunes orientated at right angles to the riverbed along its entire length. The eastern alternatives are more suitable owing to the level nature of the calcrete terrace but one complication is the fact that the Nossob River forms an international boundary between South Africa and Botswana. Furthermore, the selection of options is also affected by the desire to provide varied tourist experiences.

The aim of this paper is to assess the most likely options proposed for improving the road alignment through the consideration of a combination of expected physical impacts and diverse tourism experiences, through the interpretation of two different approaches, that of a normal subjective assessment and an objective assessment in the analysis of environmental impacts while also providing a platform for future decision making supported by defendable scientific results.

\section{Description of the habitat}

The Nossob River south of Kij-Kij is characterised by a relatively narrow (100-500 m across) valley, with the riverbed margins dominated by high dunes on the western South African side and calcrete terraces on the eastern Botswanan side. Towards the north the Nossob changes to a wide, shallow, sandy riverbed and is more than $1 \mathrm{~km}$ wide in places (Bothma \& De Graaff 1973). The silt and clayey soils (Oakleaf and Valsrivier soil forms) of the riverbeds give way to a combination of more rocky (Coega and Prieska soil forms) and shallow sandy soils (Clovelly soil form) along the riverbed margins (Van Rooyen 1984; Soil Classification Working Group 1991). The calcrete banks and ridges of the Kalahari Group (Malherbe $1984)$, are usually steep $\left(10^{\circ}-15^{\circ}\right)$ with vertical cliffs a few metres high in the upper zones (Parris 1984). However, areas comprising red, brown, yellow, cream and green sandstones, grits as well as lenses of conglomerates are also present (Malherbe 1984). The red sandy soils associated with the large dunefield are notably infertile while the pans and dry riverbeds are more fertile owning to the higher concentrations of soluble salts and exchangeable cations such as sodium, calcium, magnesium and potassium (Leistner 1959).

Vegetation along the riverbed margins comprises scattered Acacia erioloba trees with Rhigozum trichotomum, Acacia hebeclada and Galenia africana shrubs and the dominant grasses Schmidtia kalahariensis and Panicum coloratum. The plant communities in the section of particular interest in the lower Nossob riverbed have been described as Rhigozum trichotomum - Galenia africana (2b) riverine vegetation, while the adjacent dune habitat is described as an Acacia erioloba - Boscia albitrunca (8b) tree savanna (Lubbinge 1999).

\section{Methods}

The assessment of environmental impacts is often a subjective exercise given the diverse backgrounds of individual reviewers. In an attempt to determine whether a more rigorous approach to such assessments could be adopted a single survey of the lower Nossob River was undertaken by the scientific and technical services staff of the South African National Parks (SANParks) in December 1998.

Twenty-four sites distributed evenly along the $31-\mathrm{km}$ stretch of road were surveyed. Two methods were adopted in the current analysis. A purely subjective assessment, based on whether it would be desirable to have the road within the riverbed at any particular 
site, was made using aesthetic criteria such as the scenic quality, width of the riverbed, density of trees, position of the road in the riverbed, the accessibility to the riverbed margin and perceived environmental impact.

In comparison, a more rigorous assessment of each site was made by measuring a series of criteria (Table 1) that were assigned a priori values considered desirable with respect to removing the road from the riverbed. Criteria were either ranked or assigned an absolute value and then compared to that required to remove the road using multivariate statistical analysis. A Bray-Curtis agglomerative hierarchical clustering procedure that determined the similarity among sites in relation to the desirable state was undertaken to provide supporting evidence for management decisions.

Criteria that determined whether the road should be removed from the riverbed included: 1) the existing road was in the centre of the riverbed; 2 ) the riverbed was narrow $(<50 \mathrm{~m}) ; 3)$ the slope and height of the riverbed margin habitat would allow a road to be taken out; 4) the straight line visual distance of the existing road was greater than $500 \mathrm{~m}$ in either direction; 5) the existing road was below the current level of the riverbed; 6) high side-walls were present; 7) there were a large number of $A$. erioloba trees within the riverbed system; and 8) there were a number of alternative options and the potential to rehabilitate the riverbed was high.

\section{Results and discussion}

\section{Comparison between three options}

In jointly assessing the potential impacts of the three options (in riverbed, river margins or on calcrete) open to providing a road up the Nossob River, the environmental screening revealed that from an ecological perspective the best option would be to remove the road from the riverbed. Although re-routing

Table 1

Criteria used in a quantitative assessment of sites along a 31-km stretch of the Nossob riverbed, Kgalagadi Transfrontier Park. Ranks for certain criteria are in bold. The 'desired' column lists either ranks or values classified as meeting the requirements to remove the road from the riverbed

\begin{tabular}{|c|c|c|c|c|c|c|}
\hline Criteria & \multicolumn{4}{|c|}{ Parameters } & Format & Desired \\
\hline 1. Position of road in riverbed & $\begin{array}{c}\text { Botswana } \\
1\end{array}$ & $\begin{array}{c}\text { S. Africa } \\
\mathbf{2}\end{array}$ & $\begin{array}{c}\text { Centre } \\
\mathbf{3}\end{array}$ & $\begin{array}{c}\text { Out } \\
4\end{array}$ & Ranked & 3 \\
\hline 2. Width of riverbed $(\mathrm{m})$ & $\begin{array}{c}\text { Narrow } \\
50-80\end{array}$ & \multicolumn{2}{|c|}{$\begin{array}{c}\text { Intermediate } \\
80-120\end{array}$} & $\begin{array}{r}\text { Wide } \\
>120\end{array}$ & Absolute & 50 \\
\hline 3. Slope of calcrete/dune margins & $\begin{array}{c}\text { Flat } \\
1\end{array}$ & $\begin{array}{c}\text { Shallow } \\
\mathbf{2}\end{array}$ & $\begin{array}{c}\text { Gentle } \\
\mathbf{3}\end{array}$ & $\begin{array}{c}\text { Steep } \\
\mathbf{4}\end{array}$ & Ranked & 1 \\
\hline 4. Height $(\mathrm{m})$ of calcrete/dune margins & & & & & Absolute & 2 \\
\hline 5. Straight line length $(\mathrm{m})$ of road N/S & North & & South & & Absolute & $>500$ \\
\hline 6. Height of road above riverbed & Below & \multicolumn{2}{|c|}{ Level } & Above & Absolute & 0.3 \\
\hline 7. Height of road sidewalls & None & & & & Absolute & 0.8 \\
\hline 8. Large trees and shade provision & $\begin{array}{c}\text { None } \\
1\end{array}$ & $\begin{array}{c}\text { Few } \\
2\end{array}$ & $\begin{array}{c}\text { Intermed } \\
\mathbf{3}\end{array}$ & $\begin{array}{c}\text { Many } \\
4\end{array}$ & Ranked & 4 \\
\hline 9. Alternative road option possible & $\begin{array}{c}\text { No } \\
\mathbf{1}\end{array}$ & $\begin{array}{l}\text { Slight } \\
\mathbf{2}\end{array}$ & $\begin{array}{c}\text { Possible } \\
\mathbf{3}\end{array}$ & $\begin{array}{c}\text { Good } \\
4\end{array}$ & Ranked & 4 \\
\hline 10. Potential for riverbed rehabilitation & $\begin{array}{c}\text { Poor } \\
1\end{array}$ & \multicolumn{2}{|c|}{$\begin{array}{c}\text { Fair } \\
\mathbf{2}\end{array}$} & $\begin{array}{c}\text { Good } \\
\mathbf{3}\end{array}$ & Ranked & 3 \\
\hline
\end{tabular}


Table 2

Potential impacts of road alignment on three alternatives. '-ve', '+ve'refer to negative and positive impacts respectively while, ST, LT refer to impactgs in the short and long term respectively. The significance of the impact is depicted by the box shading with low significance (light shading) progressing to high significance (dark shading)

\begin{tabular}{|c|c|c|c|}
\hline Impacts & Riverbed & River edge & Calcrete \\
\hline Geology & -ve & -ve & -ve \\
\hline \multirow{2}{*}{$\begin{array}{l}\text { Soil } \\
\text { Topography }\end{array}$} & -ve & -ve & $+\mathrm{ve}$ \\
\hline & $-\mathrm{ve}$ & -ve & \\
\hline Air quality & -ve (ST) & & $+\mathrm{ve}(\mathrm{LT})$ \\
\hline Noise & -ve (ST) & -ve & -ve (ST) \\
\hline Surface water & -ve & -ve & $+\mathrm{ve}(\mathrm{LT})$ \\
\hline Ground water & -ve (LT) & $+\mathrm{ve}$ & + ve (LT) \\
\hline Land use & -ve (LT) & -ve & + ve (LT) \\
\hline Sensitive landscape & $-\mathrm{ve}$ & -ve & $+\mathrm{ve}(\mathrm{LT})$ \\
\hline \multirow{2}{*}{$\begin{array}{l}\text { Visual aspects } \\
\text { Archaeological sites }\end{array}$} & -ve & $+\mathrm{ve}$ & \\
\hline & -ve? & & \\
\hline \multirow{2}{*}{$\begin{array}{l}\text { Cultural interest } \\
\text { Socio-economics }\end{array}$} & -ve? & & \\
\hline & & $?$ & $?$ \\
\hline $\begin{array}{l}\text { Socio-economics } \\
\text { I\&AP's }\end{array}$ & -ve & & + ve (LT) \\
\hline Fauna & -ve & -ve & -ve (ST) +ve (LT) \\
\hline Flora & -ve & -ve & -ve (ST) +ve (LT) \\
\hline \multirow{3}{*}{$\begin{array}{l}\text { Threatened species } \\
\text { Wilderness experience } \\
\text { Game migration }\end{array}$} & $?$ & $?$ & $?$ \\
\hline & -ve & -ve & +ve (LT) \\
\hline & & & \\
\hline Wildlife management & -ve & & \\
\hline \multirow{2}{*}{$\begin{array}{l}\text { Ecosystem functioning } \\
\text { Tourism }\end{array}$} & -ve (LT)? & -ve & $+\mathrm{ve}$ \\
\hline & -ve (ST) +ve (LT) & $+\mathrm{ve}$ & + ve (LT) \\
\hline
\end{tabular}

the road onto the edge of the riverbank alleviated some of the problems, the best option would be to re-route the road onto the calcrete terraces along the eastern bank of the riverbed within Botswana (Table 2).

Many of the impacts were not considered to be significant in the long-term but three were identified where the potential impacts could be significant and included the impact on surface and ground water, and flora as summarised below:

\section{i) Surface water}

Raising the road surface above the adjacent riverbed surface could have a significant negative impact on the surface water flow owing to water collecting next to the road (currently water collects within the road and behind the road sidewalls). This could also possibly influence the sub-surface water flow and consequently vegetation growth and animal use of the habitat. In this regard the technical services thought the raising of the road would have no ecological impact with damming alleviated through the construction of series of shallow drifts.

ii) Ground water

The compaction of the new road by heavy machinery as well as using gravel (a relatively foreign material in the predominantly clay based riverbed) for the upgrading process as opposed to alternative materials deposited on the road side-walls from grading activity was expected to have a negative 


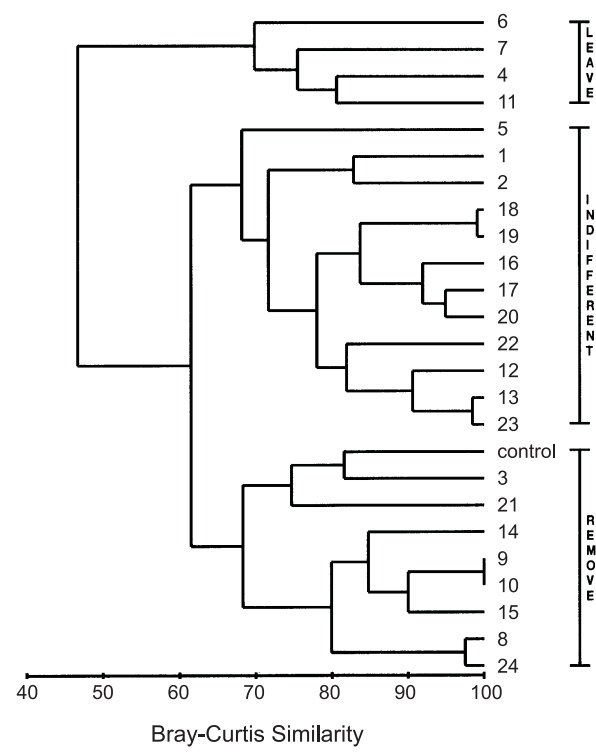

Fig. 1: Bray-Curtis clustering dendrogram identifying the associations between the 24 sites and a hypothetical control.

impact on the subsurface ground water movement. Although calcrete from the adjacent ridges and river banks is periodically assimilated within the riverbeds the use of gravel may affect the drainage patterns in the riverbed and consequently vegetation growth. The duration of these effects is also unknown although it could be reduced with time as sediments stabilise. The gravel requirements would also need to be met using local material and extensive burrow pits in the adjacent calcrete outcrops would have to be excavated.

iii) Flora

The significant impact on the flora of the riverbed is largely influenced by the effects on the surface and ground water components as discussed above. Should damming of the water continue irrespective of whether the road is elevated above the existing riverbed level then it is likely that there will continue to be clumping of vegetation alongside the road margins. However, should the water flow be more evenly spread across the riverbed away from the road then there is a possibility that it may encourage vegetation growth within the riverbed. Impacts on ecological processes were considered signifi-

Table 3

Comparison of 24 sites along the Nossob river bed based on a subjective and objective analysis of aesthetic and bio-physical criteria

\begin{tabular}{c|l|l|}
\hline \multicolumn{2}{l}{ Site Subjective } & Objective \\
\hline 1 & & \\
\hline 2 & & \\
\hline 3 & & \\
\hline 4 & & \\
\hline 5 & & \\
\hline 6 & & \\
\hline 7 & & \\
\hline 8 & & \\
\hline 9 & & \\
\hline 10 & & \\
\hline 11 & & \\
\hline 12 & & \\
\hline 13 & & \\
\hline 14 & & \\
\hline 15 & & \\
\hline 16 & & \\
\hline 17 & & \\
\hline 18 & & \\
\hline 19 & & \\
\hline 20 & & \\
\hline 21 & & \\
\hline 22 & & \\
\hline 23 & & \\
\hline 24 & & \\
\hline & & \\
\hline
\end{tabular}




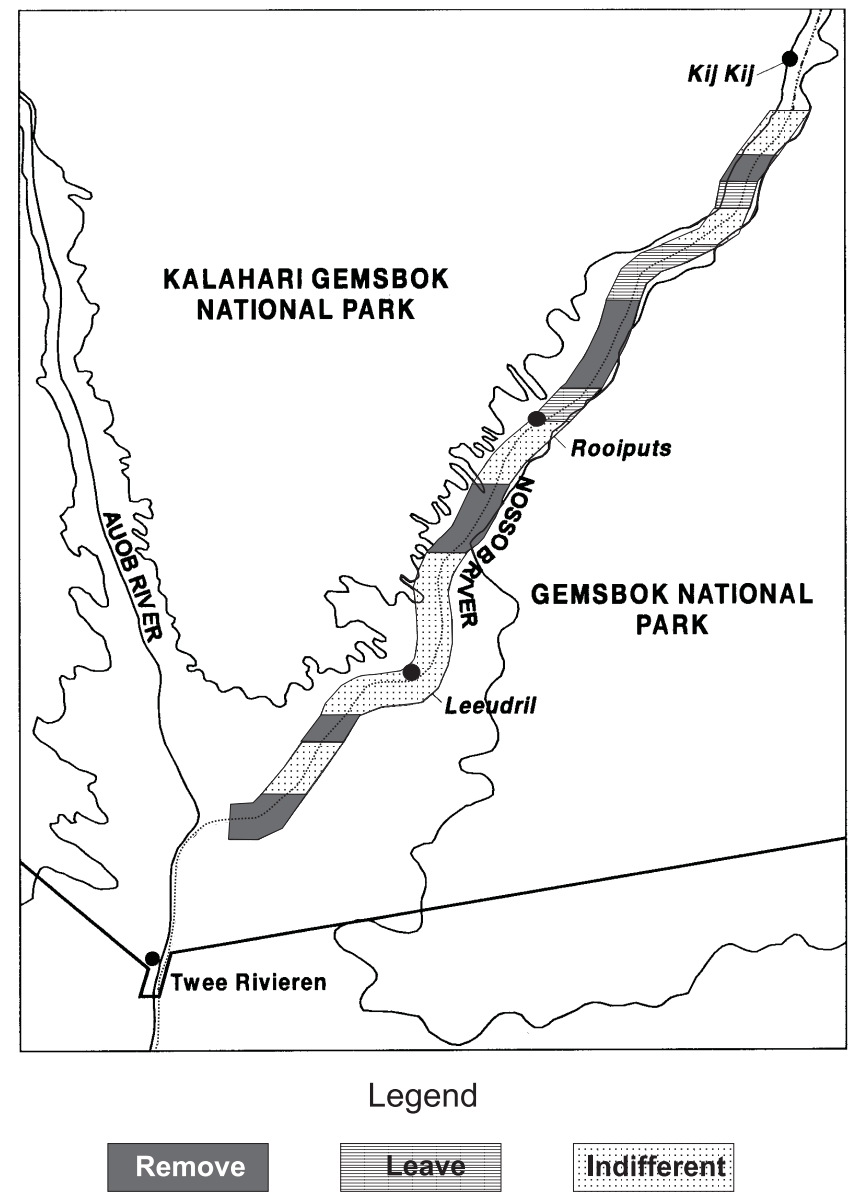

Fig. 2: Map depicting zones within the river bed which were identified based on the objective classification of bio-physical data.

cant although uncertain as to what the expected outcome may be, given the degree to which water was dispersed and allowed to penetrate into the subsoil. Whatever the case, with the riverine vegetation considered the single most important habitat in the park, the ramifications would be more than likely long-term and negative.

Moving the road onto the river edge or bank was expected to only have a significant negative affect on the geology owing to the need to cross drainage lines, while having relatively minor negative impacts on most of the other bio-physical aspects, but a minor positive affect on tourism, aesthetic appeal and ground water movement. The calcrete terrace option offered mainly positive impacts on the soils, ground water, sensitive landscape, and tourism, with minor, short-term negative impacts on noise, fauna and flora. The noise element was considered to be a factor given the greater noise produced by driving on the gravelled surface. 
Assessing re-routing options: "apples and oranges"

Although the option of removing the road out of the riverbed was considered the most desirable alternative, the need for a compromise between the perceived negative ecological impacts of maintaining the road in the river and the need for providing a variety of tourism viewing and experience options existed. In this context the selection of definite removal sites had to be identified.

Three broad groupings were identified within the cluster analysis approach for dealing with the road (Fig. 1). Eight sites (33\%) were associated with a $68 \%$ similarity with the desirable state, and thus represented those positions along the riverbed where it was most desirable to remove the road. Four sites $(17 \%)$ were identified as being acceptable to retain the road at its present alignment within the riverbed, while the remaining sites were considered to be acceptable either within the riverbed or moved out.

The subjective assessment of whether or not the road should be removed from the riverbed produced a similar picture to the clustering analysis (Table 3). Twelve sites $(50 \%)$ were identified as candidate areas to re-route the road of which there was $70 \%$ congruence with the quantitative analysis. However, the subjective approach identified a further four sites (numbers: 5, 6, 13, \& 23) as not being ideal to keep the road within the riverbed while a further five sites (numbers: $1,2,12,19, \& 22)$ were identified as being acceptable to keep the road in the riverbed. The higher percentage contributions to either the retention or removal of the road may reflect the subjective nature of the assessment where one would be inclined to group sites within specific "yes / no" groups as opposed to an undecided grouping. The conformity of the two approaches supports the notion of using the statistical approach in selecting pertinent alternatives when one has to produce a defendable product against criticism of subjective bias.

\section{Conclusions}

Although the removal of the road entirely from the sensitive riverine habitat was considered the most ecologically responsible action there is a need to compromise the ecological and aesthetic requirements of providing reasonable tourism opportunities within the park. It is recommended that the road be re-routed in and out of the riverbed, avoiding sensitive sites as indicated in Fig. 2. The use of an alternative quantitative approach in selecting these sensitive sites proved successful, making its recommendations more defendable than biased subjective alternatives.

\section{Acknowledgements}

The management staff of the Kgalagadi Transfrontier Park are thanked for their cooperation during the assessment. Andre du Plessis of South African National Park's Technical Department is also thanked for his input. Valuable comments were received from two anonymous reviewers.

\section{References}

Bothma, J. Du P. \& G. De GraAfF. 1973. A habitat map of the Kalahari Gemsbok National Park. Koedoe 16: 181-188.

DEAT 1998. EIA regulations. Implementation of sections 21,22 \& 26 of the Environmental Conservation Act. Pretoria: Department of Environmental Affairs and Tourism.

FARMER, A.M. 1993. The effects of dust on vegetation-a review. Environmental Pollution 79: 63-75.

HeRHOLDT, J.J. 1995. The breeding status (19881994) and management of raptors in the Kalahari Gemsbok National Park. Unpublished M.Tech thesis. Pretoria Technikon.

HouRdEQuin, M. 2000. Introduction: ecological effects of roads. Conservation Biology 14: $16-17$.

KNight, M.H., A.K. KNight-ElofF, \& J.J. Bornman. 1987. The importance of borehole water and lick sites to Kalahari ungulates. Journal of Arid Environments 15: 269-281.

LeISTNER, O.A. 1959. Notes on the vegetation of the Kalahari Gemsbok National Park with special reference to its influence on the distribution of antelopes. Koedoe 2: 128-151. 
LuBBIngE, J.W. 1999. A phytosociological analysis of the southern Kalahari dunes. Unpubl. M.Sc. Thesis, University of Pretoria.

Malherbe, S.J. 1984. The geology of the Kalahari Gemsbok National Park, 1931-1981. Koedoe Supplement: 33-44.

Miller, K., M.H. Allegretti, N. Johnson, \& B. JONSSON. 1995. Measures for conservation of biodiversity and sustainable use of its components. Pp. 915-1062. In: HeYwood V.H. \& R.T. Watson (eds.). Global Biodiversity Assessment. Cambridge: UNEP, Cambridge University Press

Mills, M.G.L. \& P.F. Retief. 1984. The response of ungulates to rainfall along the riverbeds of the southern Kalahari, 1972-1982. Koedoe Supplement, 129-142.
PARRIS, R. 1984. Pans, rivers and artificial waterholes in the protected areas of the south-western Kalahari. Koedoe Supplement, 63-82.

PienaAR U. DE V. 1968. The ecological significance of roads in a national park. Koedoe 11:169-174.

Trombulak, S.C. \& C.A. Frissell. 2000. Review of ecological effects of roads on terrestrial and aquatic communities. Conservation Biology 14: $18-30$.

Van Rooyen, T.H. 1984. The soils of the Kalahari Gemsbok National Park. Koedoe Supplement 4562.

VAN WyK P. \& E.A.N. Le Riche. 1984. The Kalahari Gemsbok National Park, 1931-1981. Koedoe Supplement: 21-33. 